\title{
Choice for Goods under Threat of Destruction
}

Throughout the world, government agencies and conservation organizations protect environmental and ecological services provided by undeveloped lands. In the U.S. alone, more than $\$ 50$ billion has been approved for state and local spending on land conservation since 1988; $\$ 10$ billion since 2008. ${ }^{1}$

These conservation efforts typically consider multiple parcels of land for preservation and each parcel varies in both quality (benefits provided) and cost. Given limited budgets, these efforts often cannot acquire all available parcels. When selecting which lands to conserve, most government agencies and conservation organizations use a technique known as benefit targeting

(BT), where parcels available for protection are rated in terms of attributes (e.g. presence of endangered species or protection of water quality) that reflect environmental and ecological services the properties can provide. Conservation efforts use BT to rank properties and then protect the land in order of rank until the budget is exhausted. Unfortunately, the relative cost of acquiring each property is rarely included in analysis. Numerous studies have shown that ignoring the relative cost produces a less desirable outcome in terms of environmental services acquired per budget dollar. ${ }^{2-14}$

For instance, in 2012 the National Park Service (NPS) considered 34 projects totaling nearly 93,000 acres on its National Priority List. The total cost for these projects was approximately \$110 million, which far exceeded NPS's available budget of \$25 million. Using a BT system, the NPS selected two projects in Florida: one for $\$ 5.5$ million that protected 43,000 acres in Big Cypress National Preserve and the other for $\$ 25$ million that protected 477 acres in the Everglades National Park. If costs had been taken more into account, the NPS could have re- 
allocated the $\$ 25$ million and instead of protecting less than 500 acres in the Everglades, could have protected 28,607 acres from high quality projects in a dozen different states for the same cost.

Despite the scientific evidence and examples like this one, the question remains why is BT still favored nearly exclusively by conservation organizations? A partial explanation may be that parcels are targeted because their preservation represents significant value to society through attributes such as uniqueness ${ }^{15,16}$ and that not preserving these lands may mean irreversible loss.

To test this possible explanation, we designed a framed field experiment to mimic the setting facing conservation professionals using a between-subject design consisting of two treatments differing in terms of the outcome for the non-selected good. The design has similarities to experiments by Boyce et al. (1992) involving auctioning a good that invokes intrinsic value. Our experiment was conducted with two populations: conservation professionals and economists.

In each experimental session, participants were assigned identification numbers and asked to read instructions (see Table 1). Five bottles of wine were displayed at the front of the room, and participants were instructed to confidentially select one option of red wine from the Bordeaux region of France, with each option retailing for a total of $\$ 100$ :

Option A: One bottle of wine with the highest quality score for $\$ 100$.

Option B: Four bottles of wine with high quality scores for $\$ 25$ each.

Each bottle rating in Option B varied, but all had lower ratings than the bottle in Option A. The quality scores were determined by Robert Parker's Wine Advocate rating system, which scores wine on a 0-100 scale.

Participants made selections using paper with identification numbers. At the end of the experiment, approximately $10 \%$ of the participants were randomly selected to have their choices implemented, ensuring incentive capability. 
To assess participants' baseline preferences, half the sessions were told nothing about the fate of the wine in the option not chosen (No Destruction treatment). The other sessions were told the wine in the option not chosen would be destroyed via hammer (Destruction treatment). Participants were informed that deception was not permitted in experimental economic research and administrators displayed the hammer, trash can, and safety goggles to be used.

In this experimental design, there was no a priori expectation of which option would be preferred. The expected private payout for each option was identical, while quantity and quality of the wines differed between options. However, options remained identical across treatments (Destruction, No Destruction). The good under consideration-bottles of French Bordeaux red wine - is a non-unique private good, so conventional economic theory suggests that an individual's preference structuring should not change with the treatment. The hypothesis tested is whether the threat of destruction of the option not chosen affects participants' choices. A change in observed preferences would indicate that the threat of destruction affected participants' anticipated utility, thereby causing a change in their preference as demonstrated by observed choices.

\section{Results}

Figure 1 shows the overall results from 216 adults from 76 institutions (Table 2) for each treatment. In the No Destruction treatment, $29.9 \%$ of the participants choose Option A, one $\$ 100$ bottle of highest scoring wine, and $70.1 \%$ chose Option B, four bottles of high scoring wine worth $\$ 100$. The difference is statistically significant (test of proportions; $p=0.000$ ). Under the Destruction treatment, $47.2 \%$ of participants (an increase of 57.9\%) chose Option A, a number not statistically different from the $52.8 \%$ of participants who chose Option B (test of proportions; $p=0.379$ ). 
Table 3 shows results of standard logit models where the dependent variable was the probability of a participant choosing Option A. Model A shows results for the base model where the Destruction treatment is represented by a dummy variable. Results from Model A suggest participants in the Destruction treatment were twice as likely (odds ratio=2.34) as participants in the No Destruction treatment to select Option A.

Model B tested whether participants' profession (economist or conservation professional) affected the choice made. We wanted to determine whether economists' training would generate responses systematically different from responses of conservation professionals. As shown in Table 3, the dummy variable for being an economist did not change the likelihood that a participant would select Option A $(p=0.426)$. In Model C, we included an interaction term to account for economists in the Destruction treatment. Again, there was no statistically significant change in likelihood of choosing Option A in general $(p=0.226)$ or in the specific case where destruction was threatened $(p=0.364)$. Thus, we cannot reject the hypothesis that economists and conservation professionals have similar preference for the single high-value $\$ 100$ bottle of wine when there is threat of destruction.

\section{Conclusion}

This framed field experiment provides clear evidence that the threat of destruction influenced individuals' preferences for a private good. In the No Destruction sessions, only $30 \%$ of participants preferred the single highly-rated bottle of Bordeaux. The rest preferred multiple cheaper, slightly lower-quality wine. The threat of destruction increased the likelihood that a participant would select the one highly-rated and expensive bottle of wine-in essence protecting rare wine from destruction and leaving multiple slightly lower quality wines to perhaps be destroyed. These results illustrate potential existence of an emotional and/or moral sense of 
responsibility for a good that may be destroyed. Wine and open space certainly differ in multiple ways, therefore wine and open space could enter individuals preference differently. Nevertheless these results using wine mimic choices observed in land preservation. In fact, wine is a non-unique private good, conventional economic theory suggests that an individual's preference structuring should not change with the treatment of the non-selected option. Therefore, these results for a private good may understate preferences to avoid destruction of a more special or rare public good. This outcome is also similar to earlier experiments that captured intrinsic value and a WTP/WTA disparity when considering the death of a tree ${ }^{15}$.

Our results are even more striking when considered with other evidence. Prior research on WTA/WTP suggests that property rights assignment matters to the amount of preservation that occurs. Horowitz and McConnell (2002) suggested that seven times more land could be preserved if development rights were held by the public ${ }^{17}$. Our experiment generated similar results despite not granting any property rights to participants. Future work could determine whether changing allocation of property rights would further influence likelihood of a change in preferences.

Finally, these results strongly suggest that adoption of more cost-effective practices in conservation planning is likely to continue to be met with resistance, especially in situations involving the imminent threat of destruction of a good considered special or rare in comparison to the available alternatives. The results suggest that in situations like this the current selection methods may not be as inefficient as previously believed and that new selection techniques are needed to both preserve high value lands facing imminent destruction and identify cost-effective opportunities from the other available projects. 


\section{REFERENCES AND NOTES:}

1. Trust for Public Land. (2010). LandVote Database. http://www.landvote.org

2. Underhill, L.G., 1994. Optimal and suboptimal reserve selection algorithms. Biological Conservation 70(1), 85-87.

3. Babcock, B.A., Lakshminarayan, P.G., Wu, J., Zilberman, D., 1997. Targeting tools for the purchase of environmental amenities. Land Economics 73, 325-339.

4. Ando, A., Camm, J., Polasky, S., Solow, A., 1998. Species distributions, land values, and efficient conservation. Science 279, 2126-2128.

5. Balmford, A., Gaston, K.J., Rodrigues, A.S.L., James, A., 2000. Integrating costs of conservation into international priority setting. Conservation Biology 14, 567-605.

6. Wu, J., Zilberman, D., Babcock, B.A., 2001. Environmental and distributional impacts of conservation targeting strategies. Journal of Environmental Economics and Management 41, 333-350.

7. Messer, K.D. 2006. The conservation benefits of cost-effective land acquisition: a case study in Maryland. Journal of Environmental Management 79:305-315.

8. Ferraro, P.J., 2003. Assigning priority to environmental policy interventions in a heterogeneous world. Journal of Policy Analysis and Management 22, 27-43.

9. Wu, J., 2004. Using sciences to improve the economic efficiency of conservation policies. Agricultural and Resource Economics Review 33, 18-23.

10. Newburn, D., Reed, S., Berck, P., Merenlender, A., 2005. Economics and land-use change in prioritizing private land conservation. Conservation Biology 19, 1411-1420.

11. Ferraro, P.J., Pattanayak, S.K., 2006. Money for nothing? A call for empirical evaluation of 
biodiversity conservation investments. PLOS Biology 4 (4), e105.

12. Kaiser, H.M., Messer, K.D., 2011. Mathematical Programming for Agricultural, Environmental, and Resource Economics. John Wiley and Sons, Hoboken, N.J.

13. Fooks, J.R., Messer, K.D., 2012. Maximizing conservation and in-kind cost share: applying goal programming to forest protection. Forest Economics 18, 207-217.

14. Duke, J.M., S.J. Dundas, and K.D. Messer. 2013. "Cost-Effective Conservation Planning: Lessons from Economics" Journal of Environmental Management. 125: 126-133.

15. Boyce, R.R., Brown, T.C., McClelland, G.H., Peterson, G.L., \& Schulze, W.D. (1992). An Experimental Examination of Intrinsic Values as a Source of the WTA-WTP Disparity. The American Economic Review, 82(5), 1366-1373.

16. Krutilla, J.V. (1967). Conservation Reconsidered. The American Economic Review, 57(4), 777-786.

17. Horowitz, J., \& McConnell, K. (2002). A Review of WTA/WTP Studies. Journal of Environmental Economics and Management, 44(3), 426-447. doi: 10.1006/jeem.2001.1215 
Figure 1- Percentage of Participants Choosing Each Option, by Treatment

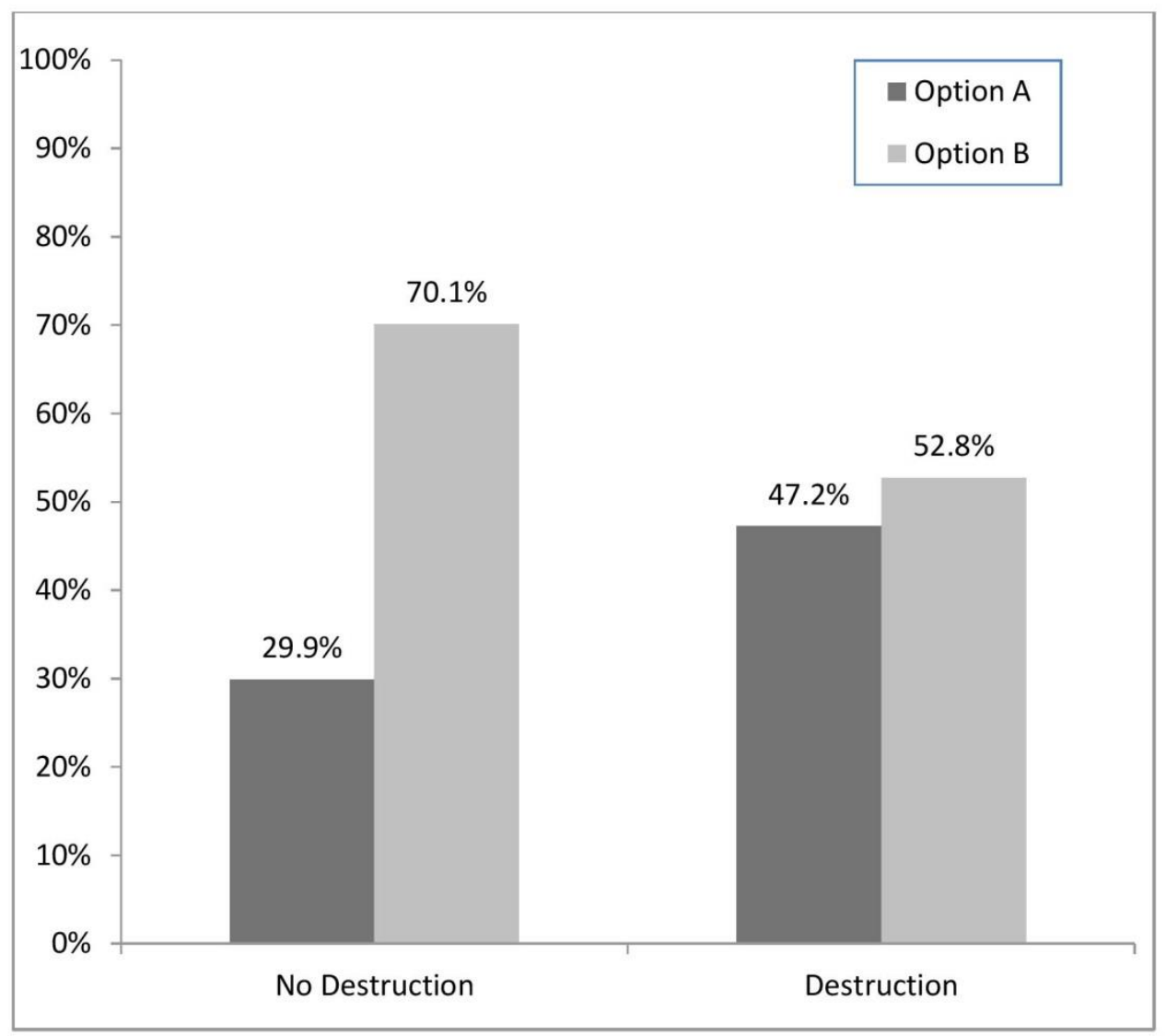


Table 1. Example of Two Wine Options

\begin{tabular}{|c|c|c|c|c|c|}
\hline & Name of Wine & Year & $\begin{array}{c}\text { Wine Advocate } \\
\text { Rating }\end{array}$ & $\begin{array}{c}\text { Retail } \\
\text { Cost }\end{array}$ & Label \\
\hline $\begin{array}{c}\text { Option A } \\
\text { One bottle of } \\
\text { Bordeaux wine }\end{array}$ & $\begin{array}{l}\text { Château Brane- } \\
\text { Cantenac }\end{array}$ & 2005 & 94 & $\$ 100$ & 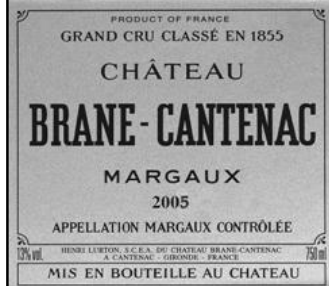 \\
\hline
\end{tabular}

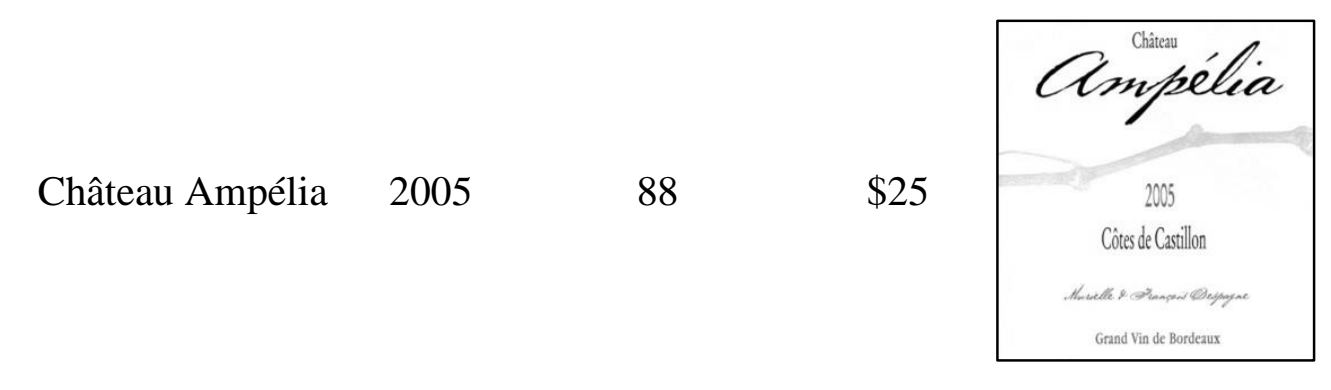

\section{Option B}

\begin{tabular}{|c|c|c|c|c|}
\hline $\begin{array}{l}\text { Château Côte de } \\
\text { Baleau }\end{array}$ & 2006 & 83 & $\$ 25$ & 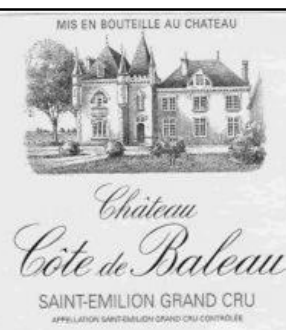 \\
\hline
\end{tabular}

Bordeaux wine

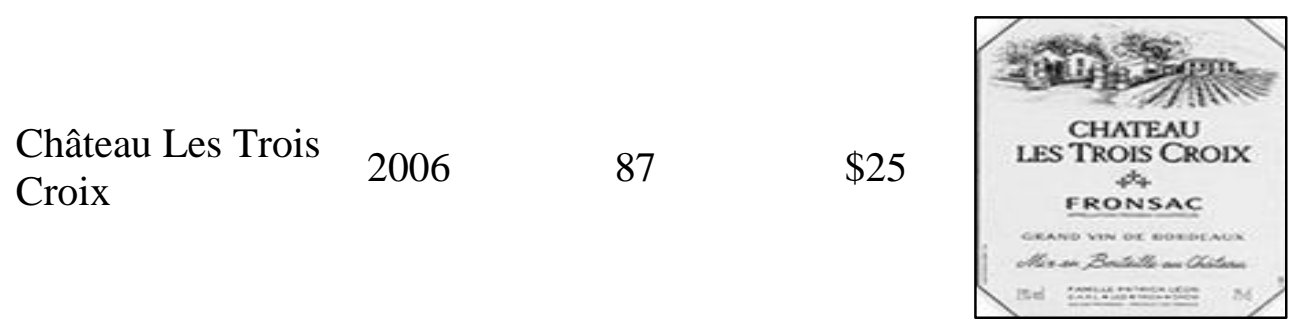

\begin{tabular}{|c|c|c|c|c|}
\hline Château Villars & 2005 & 87 & $\$ 25$ & Chàteau Villars \\
\hline
\end{tabular}


Table 2. Participant Affiliation and Location, alphabetical.

Conservation Professionals

Agriculture, Fisheries and Conservation
Department
Black Swamp Conservancy
Brandywine Conservancy
Caddo Parish
Carolina Mountain Land Conservancy
Chesapeake Bay Program
Eagle Valley Land Trust
Fairbanks North Star Borough

Foothills Land Conservancy

Green Spaces Alliance of South Texas

Greenbelt Land Trust of Mid-Missouri

Hanover Conservation Council

Harnett County

Department of Land and Natural

Resources

Lincoln Memorial University

Linn County

Inter-American Development Bank

Maryland Dept. of Natural Resources

Iowa Natural Heritage Foundation

Michigan Nature Association

Department of Natural Resources
Location Economists

Location

$\mathrm{CHN}$

Boston University

MA

$\mathrm{OH}$

Clark University

MA

PA

Clarkson University

MA

LA Columbia University

NY

NC

Cornell University

NY

MD Griffith University

AUS

$\mathrm{CO}$

Laval University

CAN

AK

National Oceanic and

DC

Atmospheric Administration

(NOAA)

TN

North Carolina State University

NC

TX

Oberlin College

$\mathrm{OH}$

MO

Pennsylvania State University

PA

NH Purdue University

IN

NC Rutgers

NJ

HI

Salisbury University

MD

TN

University of Alaska Anchorage

AK

IA

University of California-Davis

CA

N/A

University of California-Long

CA

Beach

MD

University of Colorado-Boulder

$\mathrm{CO}$

IA

University of Connecticut

CT

MI University of Delaware

DE

$\mathrm{MN}$

University of Manchester

UK 


\begin{tabular}{|c|c|c|c|}
\hline National Wildlife Refuge Association & DC & $\begin{array}{l}\text { University of Maryland-College } \\
\text { Park }\end{array}$ & MD \\
\hline Liberty Prairie Conservancy & IL & $\begin{array}{l}\text { University of Massachusetts- } \\
\text { Amherst }\end{array}$ & MA \\
\hline Natural Lands Trust & PA & University of Nevada & $\mathrm{NV}$ \\
\hline Nevada Land Conservancy & NV & University of New Hampshire & $\mathrm{NH}$ \\
\hline North Coast Land Conservancy & OR & University of Oregon & OR \\
\hline Reforestamos Mexico & MEX & University of Rhode Island & $\mathrm{RI}$ \\
\hline Santa Fe Conservation Trust & NM & University of Southern Maine & ME \\
\hline Six Rivers Regional Land Conservancy & MI & $\begin{array}{l}\text { University of Tennessee- } \\
\text { Knoxville }\end{array}$ & $\mathrm{TN}$ \\
\hline $\begin{array}{l}\text { Tall Timbers Research Station \& Land } \\
\text { Conservancy }\end{array}$ & FL & University of Vermont & VT \\
\hline Tulalip Tribes & WA & University of Virginia & VA \\
\hline USDA - Forest Service & N/A & $\begin{array}{l}\text { University of Wisconsin- } \\
\text { Madison }\end{array}$ & WI \\
\hline US Department of Transportation & N/A & University of Wyoming & WY \\
\hline US Environmental Protection Agency & N/A & $\begin{array}{l}\text { US Environmental Protection } \\
\text { Agency }\end{array}$ & DC \\
\hline US Fish \& Wildlife Service & N/A & $\begin{array}{l}\text { USDA - Economics Research } \\
\text { Service }\end{array}$ & DC \\
\hline Wallkill Valley Land Trust, Inc. & NY & Virginia Tech & VA \\
\hline West Florida Reg. Planning Com. & FL & West Virginia University & WV \\
\hline Western Pennsylvania Conservancy & PA & & \\
\hline Wyoming Land Trust & WY & & \\
\hline
\end{tabular}


Table 3. Logit Estimation Results on the Selection of Option A (one bottle of \$100 wine).

\begin{tabular}{|c|c|c|c|}
\hline Variables & Model A & Model B & Model C \\
\hline Constant & $\begin{array}{r}-0.925^{* *} \\
(0.246)\end{array}$ & $\begin{array}{c}-1.017^{* * *} \\
(0.274)\end{array}$ & $\begin{array}{c}-1.149^{* *} \\
(0.318)\end{array}$ \\
\hline Destruction & $\begin{array}{l}0.849^{* * *} \\
(0.314)\end{array}$ & $\begin{array}{l}0.868^{* *} \\
(0.316)\end{array}$ & $\begin{array}{l}1.071^{* * *} \\
(0.392)\end{array}$ \\
\hline Economist & & $\begin{array}{c}0.265 \\
(0.333)\end{array}$ & $\begin{array}{c}0.618 \\
(0.510)\end{array}$ \\
\hline Destruction $*$ Economist & & & $\begin{array}{l}-0.609 \\
(0.671)\end{array}$ \\
\hline Log Likelihood & -121.73 & -121.41 & -121.00 \\
\hline Prob $>C h i^{2}$ & 0.006 & 0.016 & 0.0287 \\
\hline Observations & 187 & 187 & 187 \\
\hline
\end{tabular}

Notes: Standard errors listed in parentheses.

${ }^{*}$ and ${ }^{* *}$ indicate levels of significance of 0.05 and 0.01 respectively.

Excludes participants who indicated familiarity with experimenters' previous discussions of comparing wine and conservation selection.

The first experiment session differed from the rest as no wine ratings were provided to participants and Option B involved five Bordeaux wines each costing \$20 rather than four bottles costing $\$ 25$. The coefficients from models with and without excluded participants and the first session were not statistically different. 
